Zabytkoznawstwo i Konserwatorstwo XLIV, Toruń 2013

\title{
Graficzna twórczość Leopolda Lewickiego w Krakowie lat 30. XX wieku i powojennym Lwowie
}

\footnotetext{
Craficzna twórczość Leopolda Lewickiego (1906-1973) z lat 30. XX $\mathcal{J}$ wieku, okresu kiedy studiował w krakowskiej Akademii Sztuk Pięknych i działał w I Grupie Krakowskiej, znacznie różniła się od jego powojennej grafiki uprawianej we Lwowie przez niemal trzy dekady. W okresie krakowskim zagorzały komunista, uczestniczacy w wiecach i manifestacjach, współtwórca Szopki krakowskiej, upatrywał sens sztuki w jej społecznym zaangażowaniu ${ }^{1}$, którego świadectwem były oszczędne, „brutalne” w formie i dosadne w swym krytycyzmie prace graficzne ${ }^{2}$. W powojennym Lwowie,
}

1 Pod wspólnym szyldem štuki rewolucyjnej kilku artystów I Grupy Krakowskiej podejmowało aktualną problematykę społeczno-polityczną - przede wszystkim w grafice. Jedno z haseł deklaracji grupy brzmiało: „Nie ma dzieła sztuki, które nie byłoby społecznym, a jeśli chodzi o jego kierunek społeczny, to ten nie zostaje określony ani tylko przez 'temat', ani tylko przez 'formę', lecz przez cały sens plastyczny, który oznacza celowe zużytkowanie wszelkich możliwości twórczych” (Margines nasæej orientacji plastycznej, „Tygodnik Artystów” 1935 z 20 kwietnia). Wiciński ujął to lapidarnie: „Surowcem sztuki, wymagającym przetworzenia na walory plastyczne, są akt, maszyna, strajk, fabryka, walka, drzewo [...] masy przecinających się form, barw, konstrukcji zdarzeń, pojedynczych fenomenów całej przyrody" (Henryk Wiciński w liście do Saszy Blondera, cyt. za: H. Hryńczuk, Grupa Krakowska 1932-1939, „Muzea Walki”. Rocznik muzeów historii walk rewolucyjnych i narodowowyzwoleńczych 1974, nr 7, s. 234.

2 Leopold Lewicki był jedynym artysta grupy z tak bogatym i interesującym dorobkiem graficznym. Inni członkowie I Grupy Krakowskiej: Jonasz Stern, Stanisław Osostowicz, Aleksander Winnicki-Radziewicz i Eugeniusz Waniek także uprawiali grafikę (tak jak 
pod presją władzy radzieckiej i konieczności dostosowania się do rzeczywistości socrealizmu, Lewicki zmuszony był do dokonania trudnych wyborów rzutujących zarówno na jego życie osobiste, jak i twórczośćs. Złagodził tak ostrą w latach 30. wymowę swoich prac, wprowadzając neutralne, niezabarwione emocjonalnie tematy; równolegle realizował prace o propagandowym charakterze.

U schyłku swojego życia Leopold Lewicki podzielił się z przyjacielem, Bogdanem Kędziorkiem, następującą refleksją:

Poczucie przynależności narodowej zawsze jest poważnie zdeterminowane. Inaczej mówiąc, losy każdego człowieka łączą się tysiącem węzłów z losem jego kraju. Podobnie należy podejść do sytuacji bardziej skomplikowanych. Normy pielęgnowane $\mathrm{w}$ przeszłości przez pokolenia w tym wypadku muszą ustapić, gdyż są dzisiaj bardzo opóźnione i prymitywne, tym bardziej że związki rodzinne u mnie tak się złożyły, że jestem obecnie podwójnie bogaty, gdyż wywodzę się z wartości, które w naszych czasach są wspólne ludziom znad Wisły i Dniepru. I taki stan rzeczy nie może dziś być objęty anatemą ${ }^{4}$.

Losy Lewickiego jako człowieka $i$ artysty splotły się nierozerwalnie z dwiema jego ojczyznami ${ }^{5}$. Tworzył w Krakowie i we Lwowie, w jakże odmiennych warunkach kulturowych i politycznych, w dwóch różnych epokach, które dzieliła przepaść II wojny światowej. Życiowe wybory podejmował z pełną świadomością osobistych pragnień i zamierzonego celu. Zgodnie z zainteresowaniami podjął w 1925 roku studia na krakowskiej ASP, porzucając wybrane wcześniej przez ojca studia prawnicze. Kilkumie-

Lewicki przede wszystkim techniki metalowe; Franciszek Jaźwiecki jako jedyny litografię), ale czynili to raczej na marginesie twórczości malarskiej. Niekiedy poszukiwali w warsztacie graficznym nowych wizualnych jakości dla kompozycji, które zaistniały wcześniej (lub później) w obrazach olejnych (Osostowicz, Waniek), przede wszystkim jednak ich prace graficzne stały się ostrzem krytyki społecznej i odzwierciedleniem reporterskiego zaangażowania artystów.

3 Zob. G. Ostrowski, Epilog polskiego sycia artystycznego we Lwowie, „Odra” 1992, nr 12, s. 42.

4 Z listu L. Lewickiego do B. Kędziorka, 09.03.1970. Fragment opublikowany w: B. Kędziorek, Leopold Lewicki. Watki monograficzne, „Zdanie” 1983, nr 5, s. 57.

5 Urodzony w 1908 roku w Burdiakowicach (koło Czortkowa) na Podolu, był synem Polaka, Jana Lewickiego i Ukrainki Olgi Bluss, a jedna z jego babek była pochodzenia żydowskiego. Żoną Lewickiego została córka Benziona Nadlera i Goldy Gofner, Henia. 
sięczny pobyt w Paryżu w pracowni Józefa Pankiewicza (przełom lat 1930 i 1931), choć zakończony wydaleniem Lewickiego z Francji za udział w demonstracji pod Ścianą Komunardów, miał niewątpliwie wpływ na postawę i światopogląd młodego artysty. Intensywna twórczość w czasach I Grupy Krakowskiej, tematyka podejmowana w grafice w latach 30. i równoległa działalność w Komunistycznej Partii Polski ${ }^{6}$ oddziaływały na siebie wzajemnie, ale wiązały się też z określonymi konsekwencjami: 18 czerwca 1932 roku władze krakowskiej ASP zdecydowały o usunięciu z wystawy prac części studentów (także Lewickiego) „z powodu antypaństwowych i antyreligijnych tytułów i niewłaściwej interpretacji artystycznej”. Artysta był kilkakrotnie aresztowany i zawieszony w prawach studenta krakowskiej ASP pod zarzutem działalności komunistycznej. Zdarzyły się też kilkakrotne rewizje w jego mieszkaniu i konfiskata kilkunastu grafik o tematyce, jak to wówczas określono, „wywrotowej”.

Wreszcie decyzja Lewickiego (powzięta świadomie, ale też pod pewna presją bieżącej sytuacji politycznej), która zaważyła na całym późniejszym życiu artysty - to wybór Lwowa jako „własnego miejsca na ziemi”. Wybuch II wojny światowej zastał Lewickiego w Czortkowie7. Po 17 września Galicja Wschodnia została przyłączona do ZSRR. Lata 1939-1941 spędził artysta jeszcze w miejscu urodzenia, następnie wraz z żoną został ewakuowany do centralnej Azji (obwód samarkandzki), gdzie w okresie 1941-1944 pracował jako nauczyciel i służył w batalionie budowlanym, a w wolnym czasie wykonał ponad tysiąc kilkaset szkiców i studiów żołnierzy i tamtejszych mieszkańców.

\footnotetext{
${ }^{6}$ Lewicki (także należący do Komunistycznej Partii Zachodniej Ukrainy, Komunistycznego Związku Młodzieży Polskiej) zaangażowany był w Krakowie w działania społeczno-polityczno-artystyczne: przedstawienia Szopki krakowskiej, pochody pierwszomajowe, wiece antyfaszystowskie, nocne akcje rozklejania plakatów antysanacyjnych i rozprowadzanie ulotek.

7 Od 1935 roku artysta mieszkał w Czortkowie, w domu rodziców, utrzymując stałe kontakty artystyczne ze środowiskiem lwowskim (mieszkał w domu artystki fotografki, Wandy Diamand) i krakowskim (wystawiał wspólnie z I Grupa Krakowska). W czasie II wojny światowej był przewodniczącym czortowskiej rady miejskiej, pracował w lokalnej gazecie „Nowe Życie”, w miejscowym Domu Armii Czerwonej. Otrzymał wysokie państwowe odznaczenia (Order Lenina, Znak Poczota, miano Zasłużonego Działacza Sztuki Ukraińskiej SRR).
} 
Pod koniec wojny artysta zastał w Czortkowie spalony dom rodzinny, osiedlił się więc w 1944 roku już na stałe we Lwowie, a tym samym stał się obywatelem ZSRR. Ten wybór okazał się nieodwracalny, determinujący dalsze życie i w znacznej mierze twórczość artysty. We Lwowie - pisał Grigorij Ostrowski -

w latach 1944-1949 dokonała się całkowita zmiana wszystkich struktur środowiska artystycznego: narodowych, społecznych, ideologicznych, a także estetycznych. Środowisko to z polsko-ukraińsko-żydowskiego stało się ukraińsko-rosyjskim. Kultura artystyczna Lwowa z „normalnej”, zmieniającej się w oparciu o zasady estetyki, stała się radziecką, w której pojęcia i kategorie okazały się dziwacznie zniekształconymi ${ }^{8}$.

Leopold Lewicki zaangażował się w artystyczne i społeczne życie Lwowa, brał udział w licznych wystawach, parokrotnie pełnił funkcje przewodniczącego zarządu obwodowego Związku Plastyków. Jako twórca cieszył się od lat 60. powodzeniem, choć treść jego prac także podlegała krytycznym ocenom władz KPZ jako niewystarczająco polityczna9. Wykształcił kilku młodych, zdolnych grafików: m.in. Wiktora Kuźmienko i Igora Ostafijczuka. Został nagrodzony orderami i honorowymi tytułami i wydawać by się mogło - jak zauważył Ostrowski - że jego życiowe i artystyczne losy potoczyły się w pełni pomyślnie, a jednak doświadczał „dramatycznych, nawet tragicznych przeżyć” ${ }^{\prime 10}$ związanych z narzucona artystom przez władze radzieckie koniecznościa „przestrajania się”. Kraków pozostał dla Lewickiego ważnym miejscem; w 1962 roku odwiedził tu Jonasza Sterna, jednego z kilku ocalałych po pogromie wojennym artystów z Grupy Krakowskiej - przyjaźń ta przetrwała wiele lat, Lewicki utrzymywał z nim kontakt do końca życia.

Zaangażowanie społeczne Lewickiego i mocno zakorzenione przekonania komunistyczne zaważyły już w latach 30 . na sposobie widzenia i opisywania świata ${ }^{11}$ w języku graficznej syntezy. Wskazywano na awangardo-

8 G. Ostrowski, op. cit., s. 42.

9 Watpliwości wzbudziła m.in. symbolika linorytu Stońce w klatce.

10 G. Ostrowski, op. cit., s. 46.

11 Zob. M. Branicka, Leopold Lewicki. Sztuka polityka przestonięta, „Art \& Business” 2002, nr 1-2. 
wy rodowód jego stylu: futuryzm, konstruktywizm, kubizm, ekspresjonizm; w kompozycjach abstrakcyjnych doszukiwano się echa puryzmu i symultanizmu. Leopold Lewicki uprawiał grafikę równolegle z malarstwem, choć dla większości malarzy z Grupy Krakowskiej grafika stanowiła margines działalności. Prace z lat 30, wykonane głównie w technikach metalowych (akwaforcie, akwatincie, suchej igle) i nieliczne linoryty, są przykładem zwięzłej formalnie, lecz niezwykle bogatej znaczeniowo wypowiedzi - stanowią ucieleśnienie zasady: maksimum znaczenia przy użyciu minimalnych środków.

W graficznej twórczości Lewickiego wyróżnić można dwa nurty ${ }^{12}$ : reportażowy - rejestrujący przejawy codzienności, zaangażowany w krakowską problematykę społeczno-polityczna, oraz konstrukcyjno-geometryzujący odzwierciedlający zainteresowanie artysty problematyką mechanizacji życia. Te „konstrukcyjne” akwaforty z lat 30. są świadectwem poszukiwań formalnych Lewickiego, a jednocześnie wypowiedzia na temat uprzedmiotowienia człowieka, upodobnionego do maszyny, zespolonego z nią, funkcjonującego jako jej maleńki trybik ${ }^{13}$. W okresie powojennym Lewicki powrócił do tej koncepcji w grafikach Maszyna i Drukarz, choć ta ostatnia, mimo analogicznej kompozycji, niesie zupełnie inny przekaz - praca i swoiste zespolenie z maszyną nie jest symbolem zniewolenia (jak w grafikach z lat 30.), lecz nacechowanym pozytywnie obrazem wydajnej pracy człowieka i jej wartości. Do tego nurtu wydaje się nawiązywać artysta także w innych powojennych grafikach: akwaforcie Ogniwo oraz linorytach Maski (2 wersje); prace te jednak nie odnoszą się do relacji człowiek - maszyna.

Z kolei na reporterski nurt składają się grafiki o charakterze dosadnego, ironicznego komentarza rzeczywistości, niepozbawione elementów brzydoty. Prace te są efektem obserwacji życia ulicy i przedmieść: ludzi (ro-

12 Pisałam o tym szerzej w artykule: Braydota w graficznym reportazu miejskim Leopolda Lenvickiego, [w:] Sapetne w sztukach pieknych. Brzydota, deformacja i ekspresja w sztuce nowoczesnej, Kraków 2011 oraz w artykule Grafika artystyczna w twórczości polskich artystón awangardy lat 30. XX w., AUNC. „Zabytkoznawstwo i Konserwatorstwo”, red. D. Markowski, 2012, t. 43, s. 201-219.

13 Dotyczy to akwafort: Robotnicy w fabryce (1932), Pray warsztacie (1932), Konstrukcja (1931/32), Komposycja (1932) oraz Kompozycja duża i Komposycja mała (obie z 1933 r.), w których coraz bardziej redukowane elementy figuratywne sprowadzone są do zazębiających się figur geometrycznych. 
botników, chłopów, bezdomnych, sytych i głodnych, kapitalistów i komunistów, policjantów i więźniów), wydarzeń (wieców, strajków, manifestacji, walk klasowych, pogrzebów, pożarów), emocji i stanów duchowych (Zakochani - Mitość pod triynastka, Rozmodlona, Spowiedź, Modty [Niewolnicy]). Artysta podjął też w trzech pracach tematykę żydowskiej szkoły (Mełamed) i łaźni (Mikwa, Żydowska taźnia). Znanych jest kilka prac inspirowanych grafika dawna (m.in. akwaforty z 1930 r. Akt kobiecy z lampa naftowa, Adam $i$ Ewa wg Rembrandta). Prace przedwojenne wykonane w technikach wklęsłodruku to kompozycje linearne o syntetycznej, ekspresyjnej formie ${ }^{14}$; w części z nich Lewicki poprzestawał na pospiesznym, jakby fragmentarycznym obrysie i arabesce linii, w niektórych różnicował fakturę ${ }^{15}$. W linorytach natomiast dominuje lapidarna czarna plama i kontur charakteryzujący sylwety w ogólnym zarysie (Przestuchanie pioniera, Scena uliczna, Prosięta).

Grafiki Lewickiego z akcentami krytyki społecznej i odautorskiego komentarza (zawartego choćby w tytułach) przedstawiały w zwartej, syntetycznej formie codzienność szarej ulicy - ulicy „kategorii B”: ubogich przedmieść, fabryk, zrezygnowanych bezrobotnych, petentów w biurach, więźniów na przesłuchaniach, głodujących nędzarzy - w opozycji do tępych, sytych urzędników, biurokratów, policjantów i strażników więziennych, kapitalistów, którzy nawet pochówek mają „pierwszej klasy” (Pogrzeb I klasy $w$ zestawieniu z Pogrzebem III klasy $\left.{ }^{16}\right)$. Dynamiczne sa sceny demonstra-

14 Twórczość graficzną Lewickiego oceniał m.in. J. Guttler: „Dobrym grafikiem jest Lewicki. Należy on do tych nielicznych naszych grafików, którzy wypowiadają się z predylekcją w akwaforcie. Twórczość jego waha się między problematyką czysto formalną a ekspresjonizmem, przy czym w pracach ekspresjonistycznych spotykamy u niego niekiedy wyraźne akcenty krytyki społecznej. [...] Styl jego akwafort jest zasadniczo linearny, rysunkowy, ale w niektórych pracach ekspresja tematu opiera się na przeciwstawieniach świateł i cieni zebranych w kontrastujace masy” (J. G. [Guttler], Z wystaw, „Gazeta Lwowska” 1937, nr 21, z dn. 28 I, s. 4).

15 O fakturze w grafikach Lewickiego pisała przed wojna recenzentka Arkin-Wohlfeldowa („Nasza Opinia”, 1937, z dn. 26 I). Współcześnie na znaczenie faktury (jako odkrycia Lewickiego dla określenia obiektywnej, wizualnej formy materii) zwrócił uwagę Marian Ja-

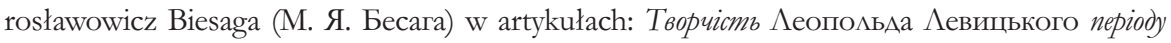
30-х років XX столітmя, „Вісник ХАААМ” (Харківська Аержавна Академія Аизайну i Мистецтв) 2006, № 1, s. 22-29 oraz КРАКІВСБКА ГРУПА ТА АЕОПОАЬА АЕВИЦЬКИЙ, „Вісник ХАААМ” 2007, № 9, s. 10-15.

${ }_{16}$ Obie prace wykonane w technice akwaforty z akwatintą w 1932 r. 
cji, wieców, walk ulicznych, przedstawienia agitatorów. Lewicki w latach 30. był w grafice mistrzem oszczędnej kreski i małego formatu. Leon Chwistek określał jego twórczość jako prawdziwa, prostą i brutalna: ,prymityw najszczerszego gatunku, wyrastający z naszej czarnej rzeczywiście płodnej ziemi’" ${ }^{\prime 1}$. W latach 1933-1939 Leopold Lewicki wystawiał swe liczne prace graficzne wraz z Grupa Krakowską we Lwowie, Stanisławowie, Krzemieńcu, Krakowie i Warszawie; w 1937 roku miał wraz ze Stanisławem Osostowiczem indywidualna wystawę w Muzeum Przemysłowym we Lwowie.

Zastanawiające jest, że po II wojnie światowej Lewicki o wiele rzadziej wypowiadał się (jeśli chodzi o grafikę) w swoich ulubionych w latach 30 . technikach metalowych. Po wojnie uprawiał linoryt (przed 1945 rokiem wykonał tylko kilka prac w tej technice) i niepodejmowaną wcześniej litografię. Wykonywał także monotypie barwne, w których powielał wcześniejsze malarskie koncepcje porządkowania kompozycji w rytmiczne, zgeometryzowane barwne pola. Poza „obowiązkowymi” gloryfikującymi realizm socjalistyczny pracami (1 Maja w moim miasteçku, portrety wodzów i żołnierzy) poszukiwania dojrzałego już artysty szły zasadniczo w innym kierunku niż w czasach krakowskich. Powojenne grafiki Lewickiego cechował rytmiczny porządek mniej lub bardziej rozdrobnionych form; były to prace bliższe malarskiej twórczości artysty, które budował na kontraście zrytmizowanych, otoczonych konturem białych i czarnych form. Zazębianie - swoiste dopełnianie się kształtów poszczególnych elementów na zasadzie puzzli odgrywało w tych kompozycjach zasadnicza rolę. Powojenna grafika Lewickiego, jak zauważyła Monika Branicka, zbliżała się raczej do ukraińskich drzeworytów ludowych, budząc skojarzenia z ilustracjami do bajek, „stała się bardziej statyczna, aby nie powiedzieć nazbyt dekoracyjna"18. Trudno nie zgodzić się z kolejnym jej stwierdzeniem, że jest to fakt zaskakujacy w porównaniu z dynamiczną w kompozycji, ostrą w wymowie i bezkompromisowa twórczością Lewickiego z lat 30. Jeśli weźmiemy jednak pod uwagę specyfikę środowiska, okoliczności i czas - a wreszcie fakt, że okres młodzień-

17 L. Chwistek, Fala optymizmu, „Czas” 1938, z dn. 6 II, cyt. za: J. Wicińska, Cžtowiek swego czasu, [w:] Cyganeria i polityka. Wspomnienia krakonskie 1919-1939, Warszawa 1964, s. 256.

${ }_{18}$ M. Branicka, Sztuka uwiktana w polityke, [w:] Leopold Lewicki. Wystawa malarstwa i grafiki ze żiorów Felicji i Bogdana Kedziorkón, Kraków 2002, s. 5. 
czego buntu i czarno-białego postrzegania świata Lewicki miał już za sobą (w roku 1945 był tuż przed czterdziestymi urodzinami), takie zmiany stają się bardziej zrozumiałe.

Tematyka powstałych we Lwowie grafik artysty jest pozornie zbliżona do przedwojennej ${ }^{19}$ : życie współczesnego miasta (z lat 30. prace: Na ulicy, Na dworcu, Na bazar, Ruch uliczny, Jarmark, Biuro pośrednictwa pracy, Legitymacje, W polu, Na drodze; z powojennych: Ruch uliczny, Miasteczko, Autobus, Osiedla, Pogrzeb, Bankiet, Cafe, Kino-Park, W foyer, W gościnie, W parku, W telefonicznej budce, Przedmieście, Zabawa i mypocsynek), ludzie i ich dzień powszedni (z lat 30.: Robotnicy w fabryce, Rzemieślnik, Handlarz uliczny, Nosiwoda, Rz̨ęnike, Najmitka, Baba z kura [Na bazar], Drwale, Palacze, Kowal, Dresyna, Dwaj robotnicy, Pray masynie, Szwaczki I i II, Rysownik; z powojennych: U kowala, Zegarmistry, Fryz̧ernia, Sprzedawnsyni kwiatów, Drukarz, Geolodsy, Akrobaci), ponadto kilka wersji Maciersyństwa z okresu krakowskiego i lwowskiego.

W grafikach powstałych po 1945 roku brak jednak wcześniejszej „drapieżności i protestu"20; kompozycja, choć nadal bardzo zwarta, ma już inny charakter. Prace o tematyce rodzajowej budował Lewicki z szeregu drobnych kwadratów tworzących swego rodzaju mozaikę (W parku, Ludzie i kondygnacje, W telefonicznej budce, Diviewczeta, Dama w okularach, Sprzedawcsyni kwiatów, Wioska, Ziemia z serii Karpaty) - postacie i obiekty wydają się złożone z drobnych elementów wypełniających całe pole obrazowe. Twarze ludzi sa zgeometryzowane, kanciaste; tło budowane na zasadzie horror vacui - w każdym milimetrze szczelnie wypełnione powtarzalnymi rytmicznymi formami: kwadracikami, punktami, równoległymi kreskami. W szczególnym natężeniu artysta zastosował ten zabieg w linorytach: Osiedle, $W$ parku, Ludzie $i$ kondygnacie, Sprzedawcsyni kwiatón; w litografii Zabawa i mypocsynek oraz Plasy (w obu wersjach: litograficznej i linorytniczej z lat 60.). Sa to prace zasadniczo odmienne od przedwojennych, „lizejszych” wizualnie akwafort, w których głównym budulcem i środkiem ekspresji była pojedyncza lub zwielokrotniona dynamiczna linia charakteryzująca postać lub sytuację, a tło pozostawało neutralne (np. w pracach: Mitosíc pod traynastka, Musy)kan-

19 Z wyjątkiem motywów typowych dla „sztuki rewolucyjnej” lat 30., choć i po $1945 \mathrm{r}$. pojawiaja się pojedyncze linoryty zatytułowane: Strajk, Protest, Walka.

${ }_{20}$ M. Branicka, Sztuka uniketana w polityke, s. 5. 
ci, Modty, Chtopi, W malarskiej pracowni, Siedzacy, Rodzina buduje dom i wiele innych). Natomiast przenikanie form, nakładanie na siebie transparentnych elementów kompozycji Lewicki stosował w grafice zarówno w okresie krakowskim, jak i powojennym, przy czym w latach 30 . było to raczej przenikanie i nakładanie linii, natomiast po 1945 roku - płaszczyzn o określonym kształcie i wielkości. Z przedwojennych akwafort dobrym przykładem sa: Jarmark, Gtodni i syci, W tą̧ni àydowskiej, Mikwa, Fabryka (Agitator), a z okresu powojennego, niezwykle interesujące, znakomite litografie Zabawa $i$ mypocsynek, Plaża, Zegarmistry, Geolodsy.

W czasach lwowskich Lewicki tworzył także prace na granicy abstrakcji, w których zespoły zgeometryzowanych, czarnych, białych bądź wypełnionych zróżnicowanym deseniem niefiguratywnych form łączył z sugestia postaci lub przedmiotu w tytule danej kompozycji (np. linoryty Wychowawczyni, Walka, Taniec, Las). W okresie krakowskim, poza kompozycjami „konstrukcyjnymi” dotyczącymi relacji człowiek - maszyna, takie rozwiązania nie pojawiły się, a jedynym chyba, najbliższym przykładem jest akwaforta Macieraynístwo z 1932 roku. Natomiast wykonane na przełomie lat 60. i 70. w technikach wypukłodruku abstrakcje: Arcbitektura, Miasto, Miasto w nocy, Nowe miasto są już „tylko” rozegraną na płaszczyźnie grą zróżnicowanych, skontrastowanych czernia i biela (rzadziej innym kolorem) zgeometryzowanych form $^{21}$. W powojennych grafikach Lewickiego nie brak też akcentów lirycznych - linoryt Zmrok z lat 60. czy kameralna litografia Driewncsyna nad pasjansem z 1973 (roku śmierci artysty) stanowią intrygujące przykłady umiejętnego budowania nastroju najprostszymi, właściwymi dla danej techniki środkami.

Podsumowując, należałoby wrócić do kluczowego dla tego artysty problemu, który odcisnął piętno nie tylko na jego twórczości - kwestii wyboru, kwestii przymusu:

Życie postawiło Lewickiego przed twardym wyborem: czy pójść na kompromisy, jakoś dostosować się do realnej rzeczywistości, czy... - kto wie, co stałoby się z nim, gdyby wybrał inną drogę... Artysta wybrał pierwsze i zapłacił za to najwyższą cenę: wiele dzieł, które wykonał w ostatnich dziesięciole-

21 Do podobnych rozwiązań artysta zbliża się w linorycie Urzad z 1971 roku, choć nie dematerializuje całkowicie tytułowego budynku. 
ciach, nie okazało się godne jego talentu. I nikt, być może, z wyjątkiem jego żony, nie wiedział jak surowo i bezlitośnie osądzał on siebie. Był to jeszcze jeden życiowy i twórczy dramat...22

Ten twórczy dramat i przewrotność losu przejawiły się jeszcze w innym wymiarze; jak zauważyła Monika Branicka, ,siła i bezkompromisowość sztuki Lewickiego miała źródła w jego niespotykanej wierze w idee, które jak na ironię zasłoniły po latach wspaniały warsztat i talent artysty"23. Można tylko spekulować, co by było, gdyby Lewicki został po 1945 roku w Polsce, można dyskutować o jego wyborach. Niezależnie jednak od tego należy pamiętać, że był niezwykle utalentowanym polsko-ukraińskim artystą awangardy europejskiej XX wieku (w grafice niekiedy bardziej radykalnym niż w malarstwie), a w opinii przyjaciół - człowiekiem przyjaznym, skromnym, bezpośrednim, dowcipnym i ujmującym, „o wielkim uroku osobistym pozostawiającym niezatarte wrażenie na wszystkich, którym dane było się z nim zetknąc "24. Mając na względzie taka postawę artysty (mimo jego wewnętrznego osobistego rozdarcia) i całkowite oddanie sztuce (przypomnijmy, że zmarł, pracując nad kolejna grafika) - kwestia trafnych lub mniej szczęśliwych wyborów życiowych traci na znaczeniu.

\section{Summary}

\section{Graphics by Leopold Lewicki (1906-1973) in Cracow and Lviv Milieus}

As a painter and graphic artist Lewicki worked in Cracow and Lviv in two extremely different cultural and political conditions, two different ages, separated the chasm of the Second World War. Lewicki's social involvement as well as his deeply rooted, Communist beliefs influenced his way of perceiving and describing the world, as early as the 1930s, in the language of graphic synthesis. Works created in the 1930s, composed mostly in intaglio techniques (etching, aquatint, drypoint) and few linocuts constitute the illustration of a statement that was formally succinct but possessed immensely rich meaning; they constitute the embodiment

22 G. Ostrowski, op. cit., s. 48.

23 M. Branicka, Sztuka unikłana ..., s. 5.

24 G. Ostrowski, op. cit., s. 48. 
of the rule: minimum meanings, maximum means. Intensive artistic activity in the times of the $1^{\text {st }}$ Cracow Group, the themes undertaken in his graphics in the 1930s as well as the activity in the Communist Party of Poland went hand in hand and influenced one another. Lewicki's graphic output can be divided into two trends: the documentary one that records the examples of everyday life and is involved into socio-political Cracovian themes; and the "structural-geometric" one, mirroring the artist's interest with the problems of "the mechanization of life". The works made in intaglio are linear compositions with synthetic and expressive form; in some of them Lewicki contents himself with hasty, as if fragmentary outline and arabesque of lines, in others he diversifies the texture.

The outbreak of the Second World War found him in Chortkiv. After the war, he found his Chortkiv family house burned down, so he settled in Lviv, and became a citizen of the USSR. This choice turned out to be irreversible and marked the rest of his life and, to great extent, his art. In Lvivian times Lewicki created also works on the verge of abstractions, in which groups of geometricized, black, white or filled with various patterns nonfigurative forms were connected with the idea of a figure or an object in the title of this composition. During Cracovian period, apart from "structural" compositions referring to the problems of "mechanization" of a human being, these solutions did not appear at all, and the closest example is the etching Maciersynstwo/ Motherhood from 1932. The abstractions composed at the turn of the 1960s and the 1970s in relief printing technique (woodcut and linocut), Architektura / Architecture, Miasto / City, Miasto w nocy / City at night, and Nowe miasto / New city are "merely" a game of various geometrized forms, contrasted with white and black, sometimes with different colors.

It is curious that after the Second World War Lewicki rarely employed, when it comes to graphic design, metal techniques favoured by him in the 1930s. After the war he used the linocut, before 1945 he made only several works in this technique, and the lithograph he did not employ before. He also made color monotypes in which he copied his previous painting concepts of subordinating the composition into geometricized colourful fields. Apart from "obligatory" drawings that glorified socialist realism the experiments of a mature artist were basically directed into a different direction than in Cracovian times. One can only speculate what would have happened if Lewicki had stayed in Poland after 1945; one can discuss choices he made. Regardless, one should remember that he was incredibly talented Polish-Ukrainian artist of European avant-garde of the twentieth century, in graphic art at times more radical than in painting, and in the opinion of those who knew him, a friendly, modest, open, witty, and engaging man "with great personal charm who left indelible impression on all those who were to meet him". 


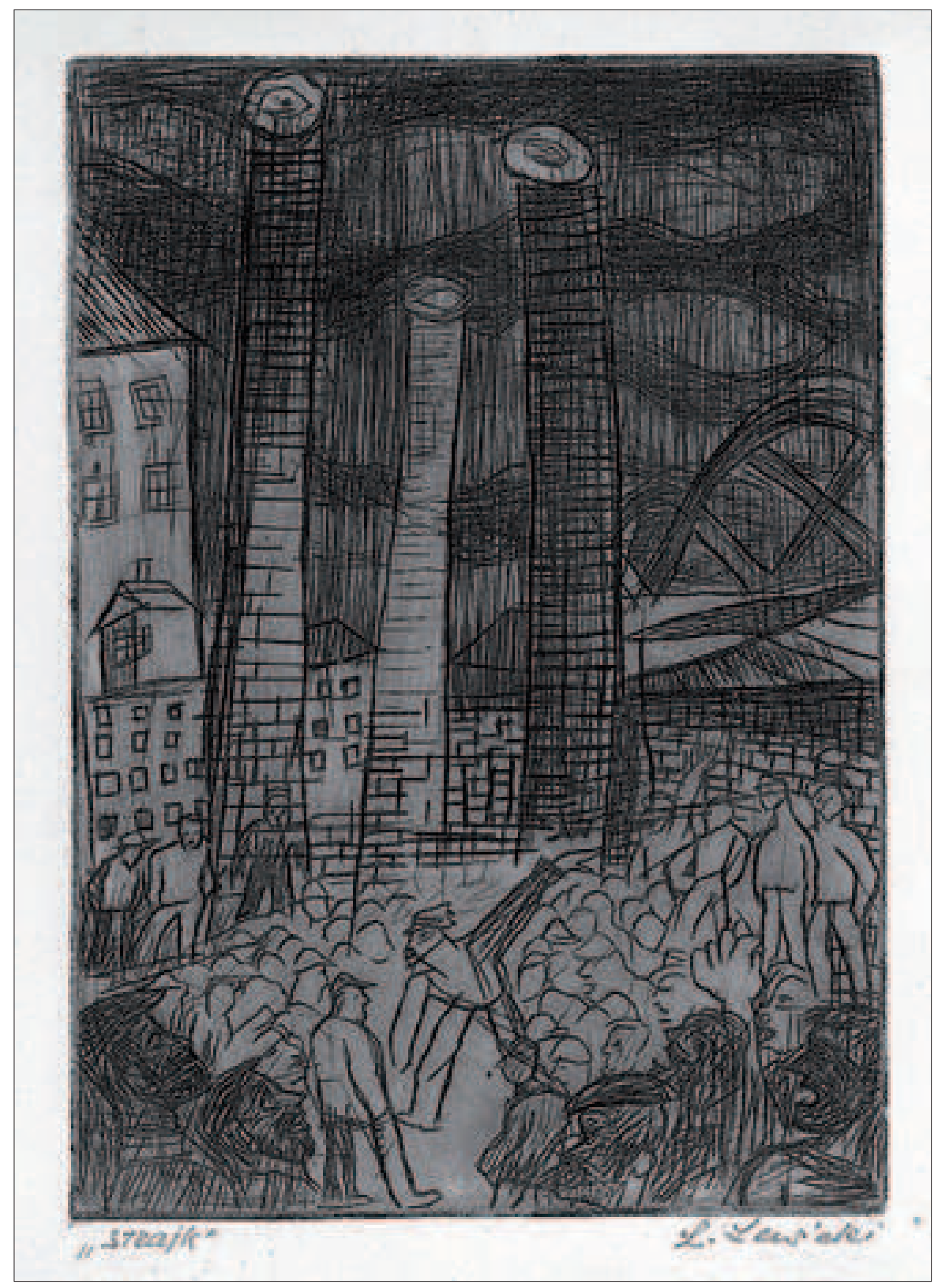

Il. 1. Leopold Lewicki, Strajk (Masónka pod fabryka), 1932, akwaforta, ze zbiorów prywatnych 


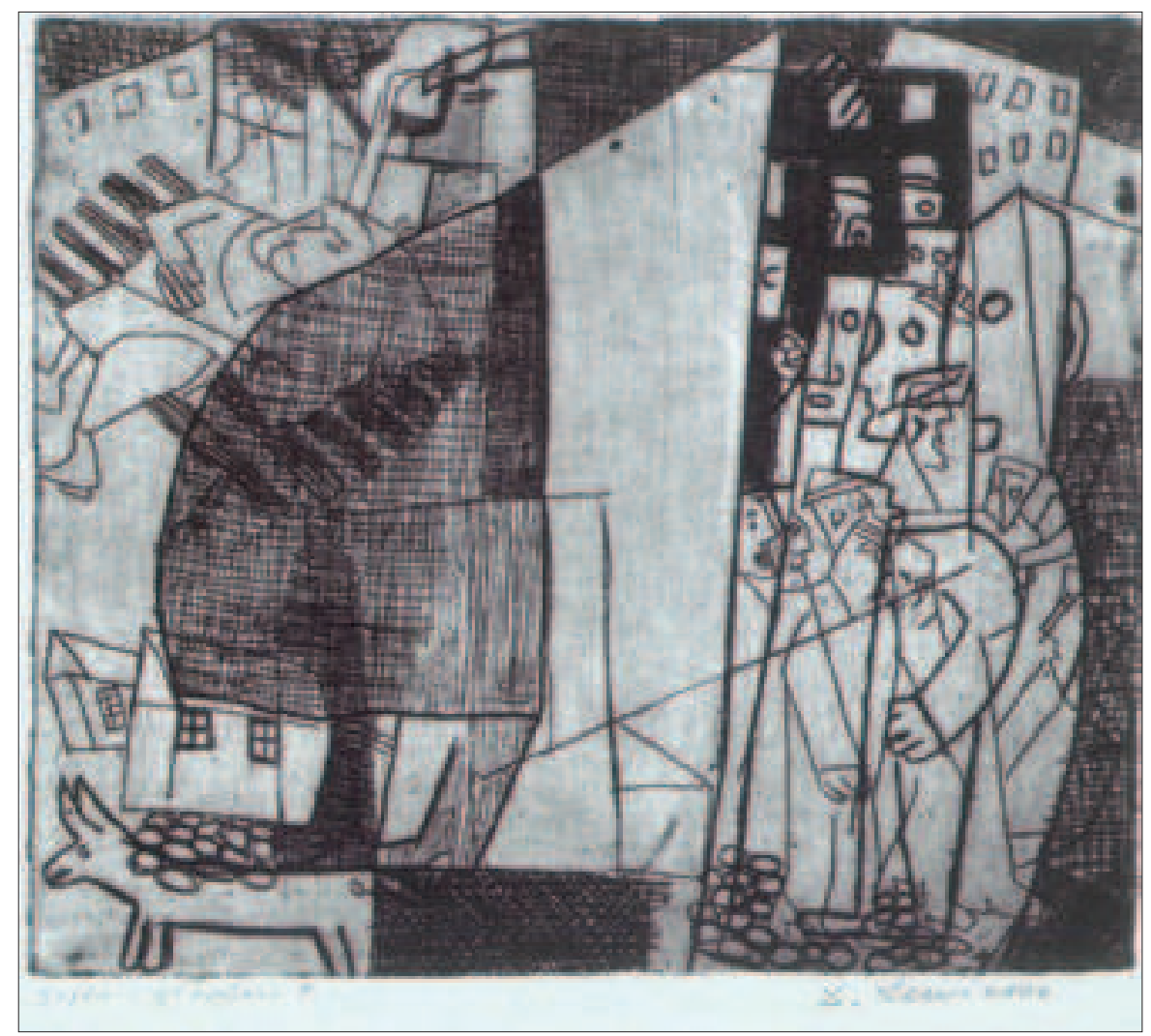

Il. 2. Leopold Lewicki, Głodni i syci, 1932, akwaforta, ze zbiorów prywatnych 


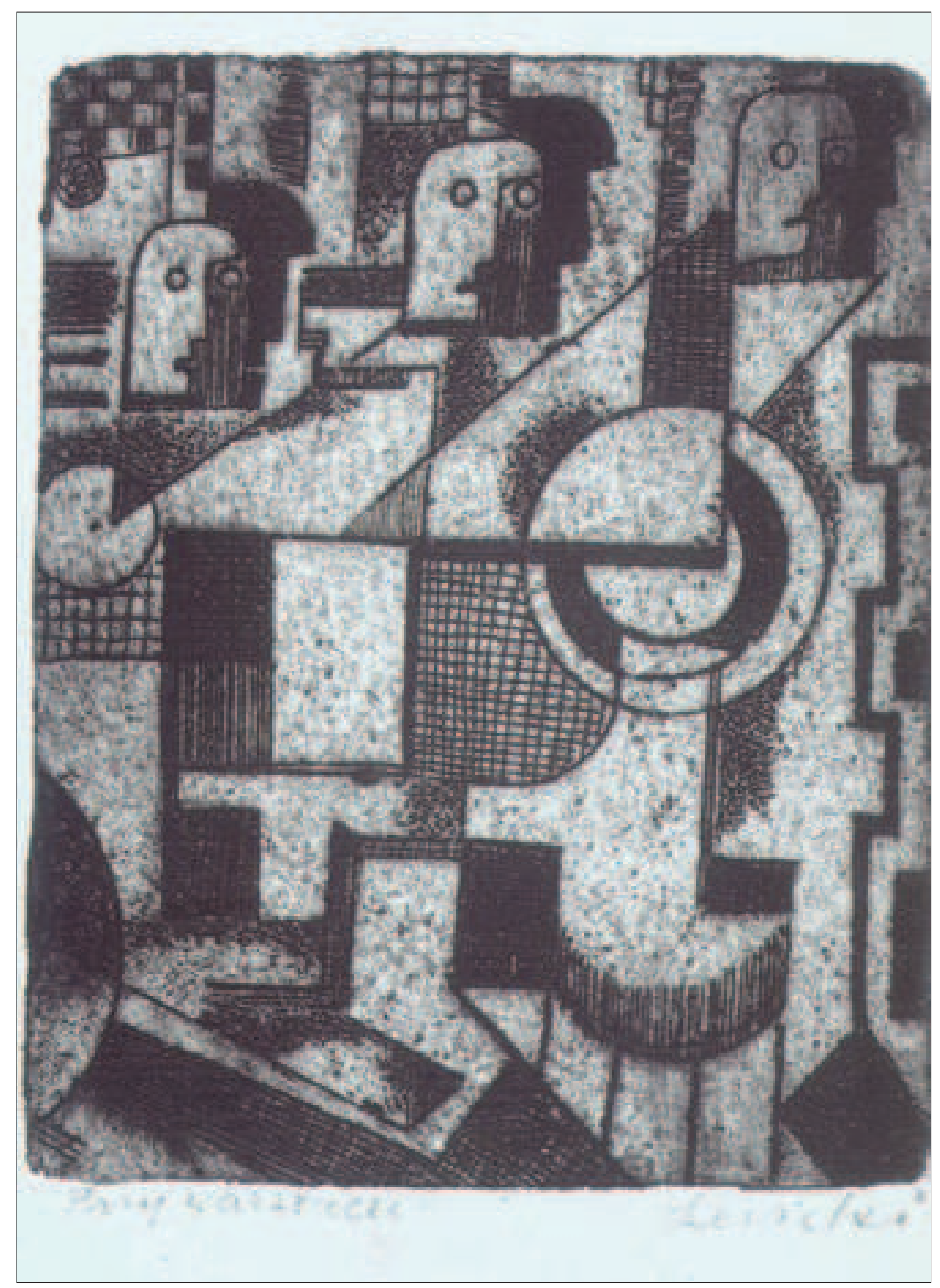

3. Leopold Lewicki, Prayy warsztacie, 1932, akwaforta, ze zbiorów prywatnych 


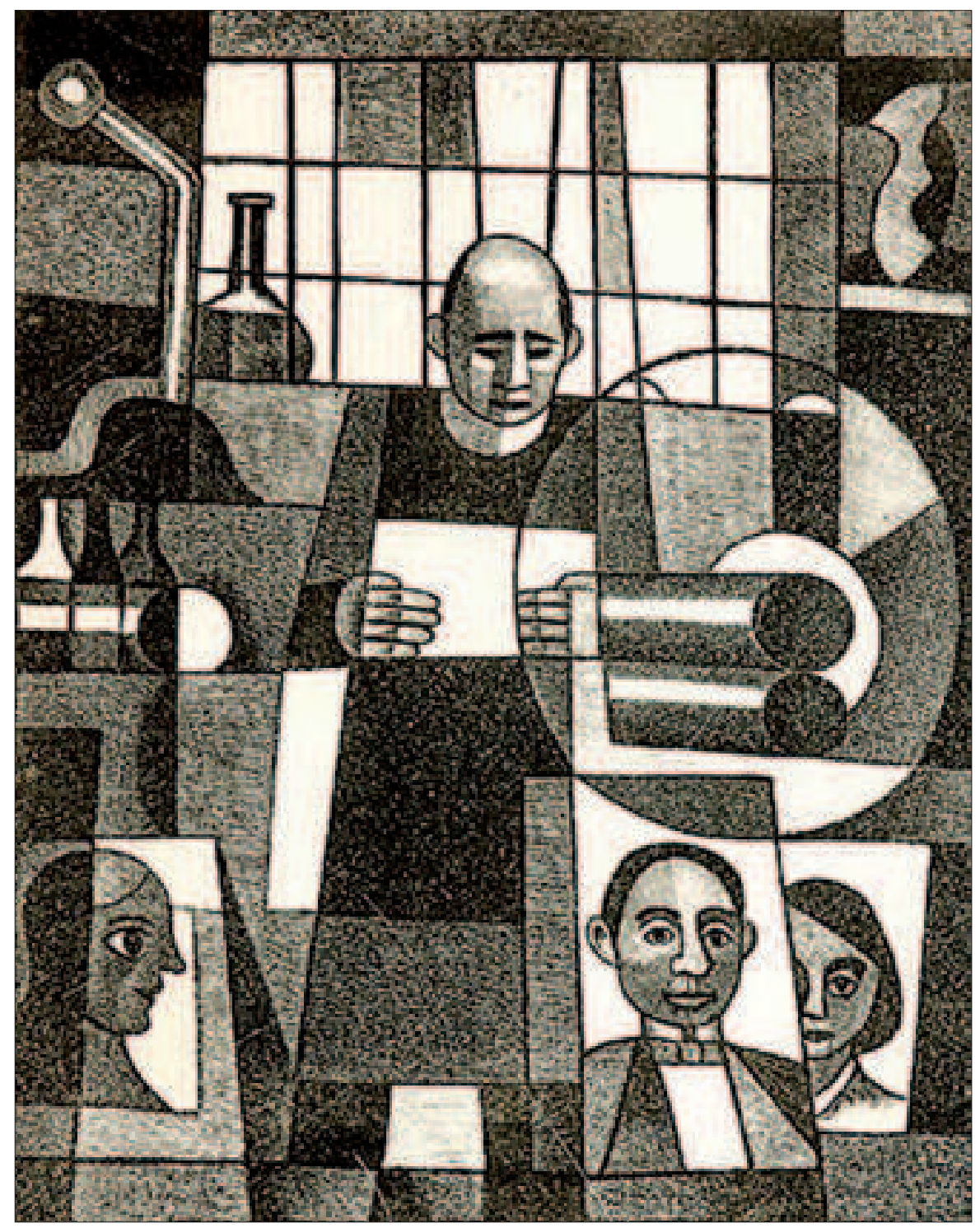

4. Leopold Lewicki, Drukarz [po 1945 r.], akwaforta, ze zbiorów prywatnych 


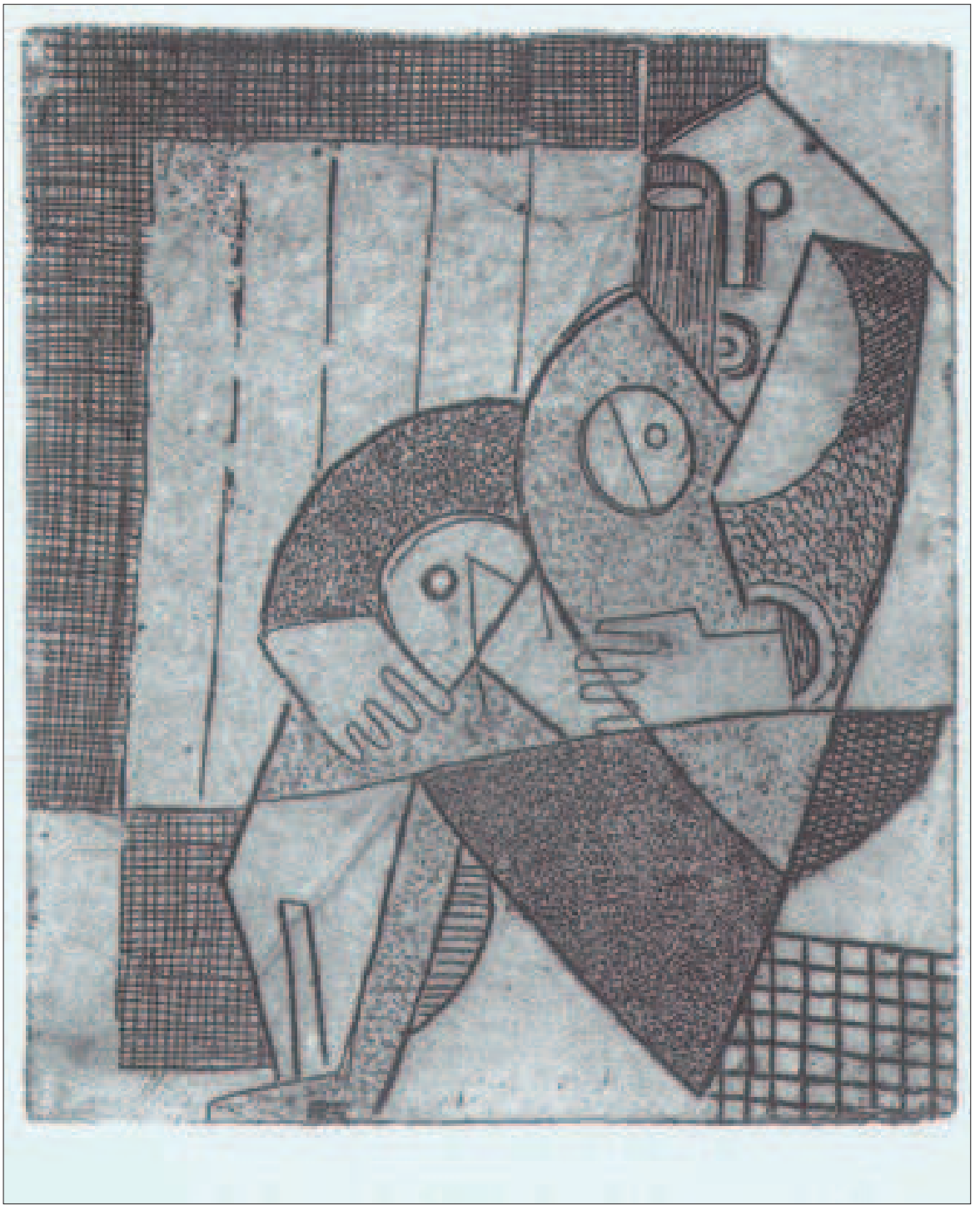

5. Leopold Lewicki, Maciersyństwo, 1932-1933, akwaforta, ze zbiorów prywatnych 


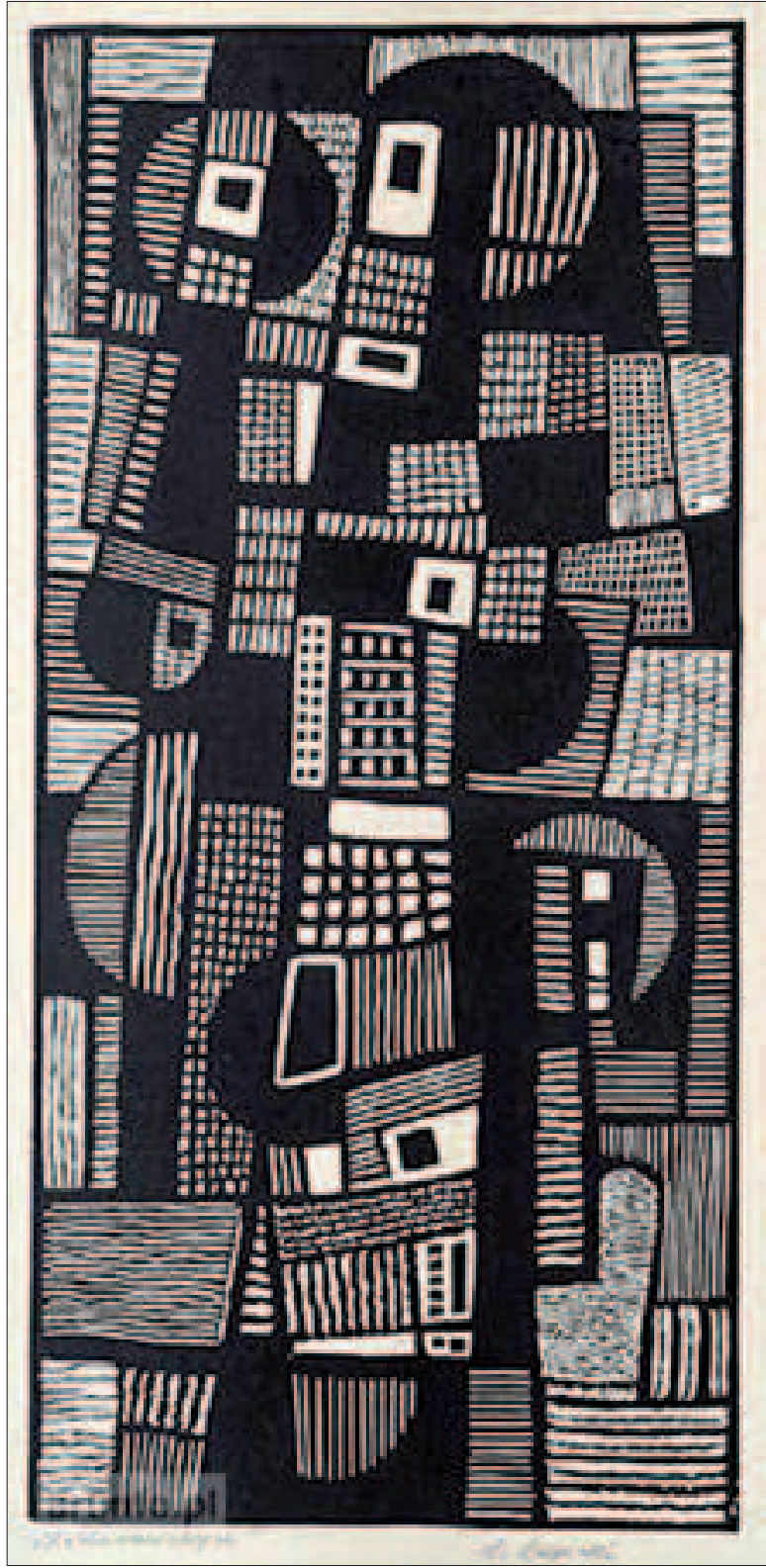

Il. 6. Leopold Lewicki, Wychowawcsyni [po 1945 r.], linoryt, ze zbiorów prywatnych 
[504]

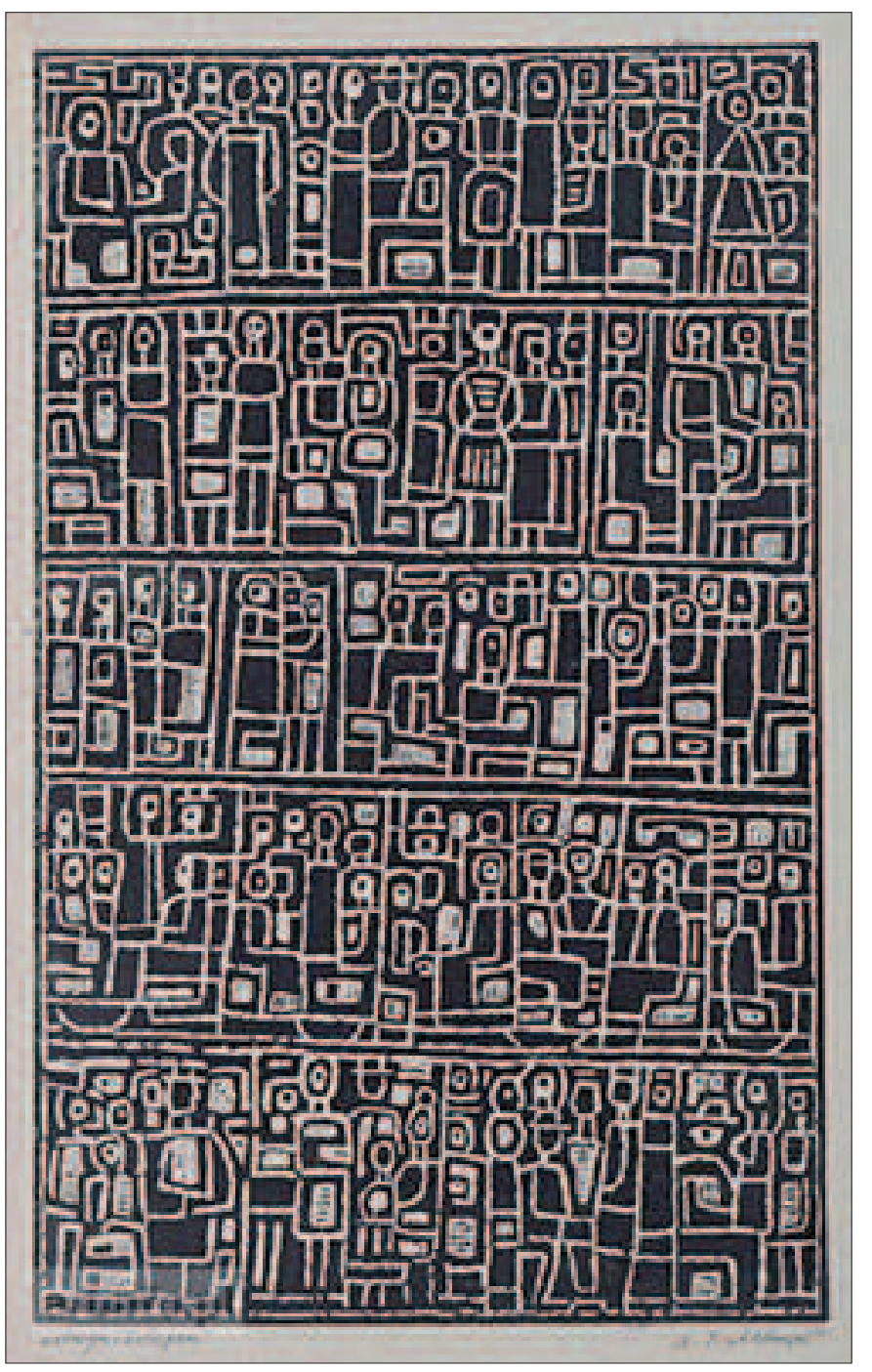

7. Leopold Lewicki, Ludzie i kondygnacje [po 1945 r.], linoryt, ze zbiorów prywatnych 


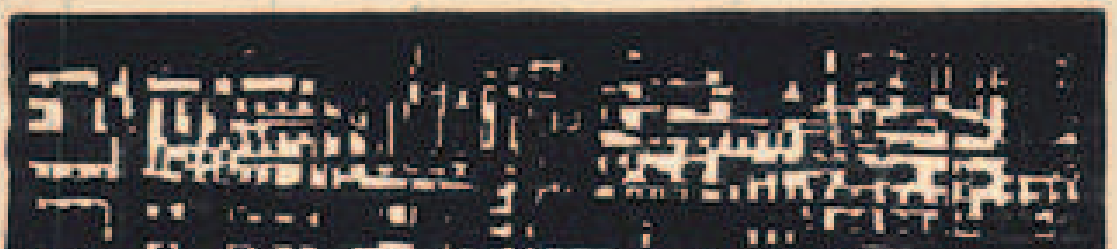

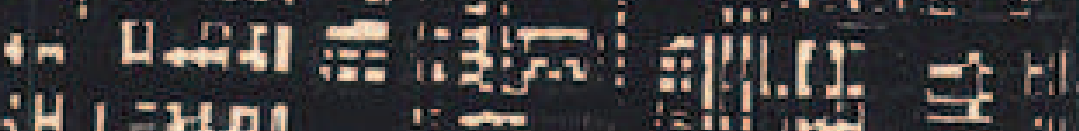

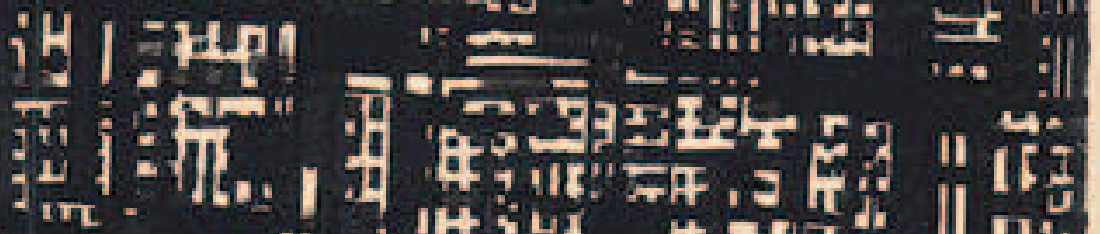

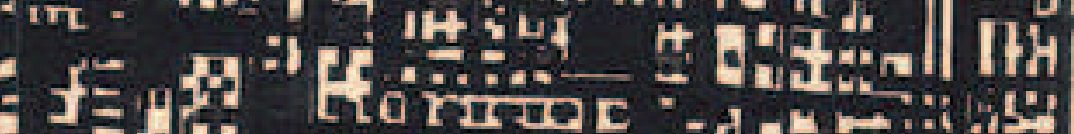

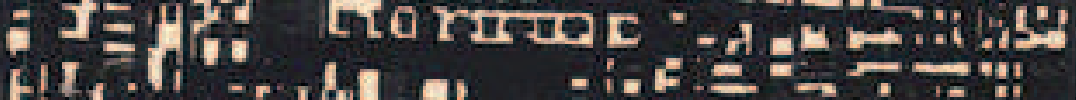

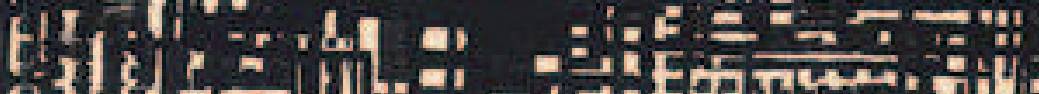

G) है

$2-i$ से स."

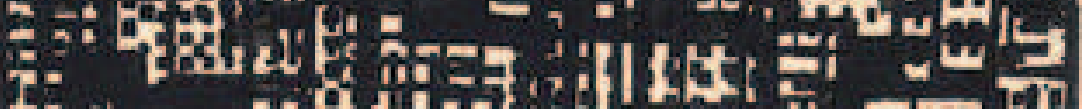

F: : it:

स्रा

;

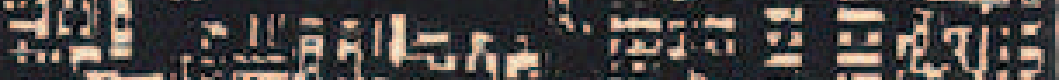

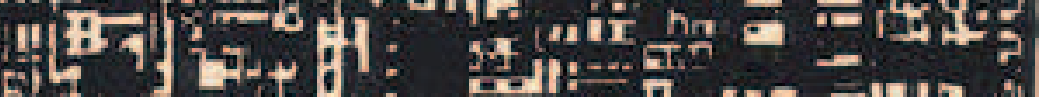

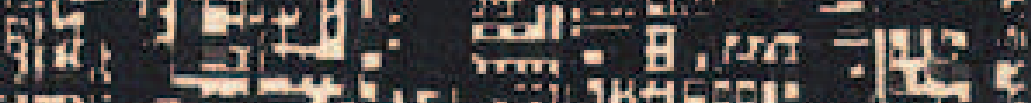

․․ -

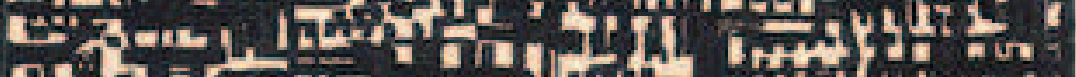
91?

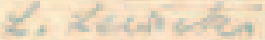

Il. 8. Leopold Lewicki, Miasto w nocy, lata 60., linoryt, ze zbiorów prywatnych 